Jurnal Riset Agama

Volume 1, Nomor 2 (Agustus 2021): 412-427

DOI: $10.15575 /$ jra.v1i2.14708

https://journal.uinsgd.ac.id/index.php/jra

\title{
Membaca Alqur'an sebagai Model Tafakkur dalam Upaya Menenangkan Jiwa di Masa Pandemi Covid 19: Studi Takhrij dan Syarah Hadis
}

\author{
Danendra Ahmad Rafdi \\ Jurusan Ilmu Al-Qur'an dan Tafsir, Fakultas Ushuluddin \\ UIN Sunan Gunung Djati Bandung, Indonesia \\ ahmadrafdidanendra@gmail.com
}

\begin{abstract}
This study aims to discuss the hadith about reading the Qur'an as a model of meditation in an effort to calm the soul during the Covid-19 pandemic. This research is classified as a qualitative research type that uses literature study by applying the takhrij and syarah hadith methods. The analytical method used in this research is contemporary analysis. The results of the study indicate that the hadith about reading the Qur'an as a model of tafakkur is valid in terms of sanad and matan according to takhrij reviews. As for the syarah of the hadith, it shows that tafakkur through reading the holy verses of the Qur'an will apparently add a sense of mahabbah to Allah SWT. This love for Allah SWT will also be developed again by reflecting on the attributes and names of Allah SWT and accompanied by good deeds. This thing will increase the faith of a human being so it will give birth a peace in the soul. The conclusion of this study is that tafakkur by reading the Qur'an can also be a medium for spiritual healing for mental problems caused by the Covid-19 virus, although reading the Qur'an is not the only way to achieve peace of mind. Further research is needed on this matter, this research also recommends the collaboration of hadith experts, tafsor experts and also psychotherapy tasawwuf experts to explore studies on tafakkur by reading the Qur'an as an effort to calm the soul.
\end{abstract}

Keywords: Alqur'an; Covid-19; Hadith; Peace of soul; Tafakkur.

\begin{abstract}
Abstrak
Penelitian ini bertujuan untuk membahas hadits tentang membaca Alqur'an sebagai model tafakkur dalam upaya untuk menenangkan jiwa di masa pandemi Covid-19. Penelitian ini tergolong jenis penelitian kualitatif yang menggunakan studi pustaka dengan mengaplikasikan metode takhrij dan syarah
\end{abstract}


Jurnal Riset Agama, Volume 1, Nomor 2 (Agustus 2021): 412-427

Danendra Ahmad Rafdi/Membaca Alqur'an sebagai Model Tafakkur dalam Upaya Menenangkan Jiwa Di Masa Pandemi Covid 19: Studi Takhrij dan Syarah Hadis

hadits. Adapun metode analisis yang dipakai dalam penelitian ini ialah analisis kontemporer. Hasil penelitian menunjukkan bahwa hadis tentang membaca Alqur'an sebagai model tafakkur ini berstatus shahih dalam segi sanad dan matan menurut tinjauan takhrij. Adapun syarah hadits menunjukkan bahwa bertafakkur melalui membaca ayat suci Alqur'an rupanya akan menambah rasa mahabbah kepada Allah SWT. Rasa cinta kepada Allah SWT tersebut juga akan dapat dikembangkan lagi dengan bertafakkur tentang sifat-sifat dan nama-nama Allah SWT dan diiringi dengan amalan-amalan. Hal inilah yang kemudian akan meningkatkan keimanan seorang manusia sehingga akan melahirkan ketenangan dalam jiwa. Kesimpulan dari penelitian ini ialah bahwa tafakkur dengan membaca Alqur'an ini pun dapat menjadi sebuah media terapi spiritual atas problem jiwa yang ditimbulkan karena virus Covid-19, meskipun membaca Alqur'an ini bukanlah satu-satunya cara untuk menuju ketenangan jiwa. Dibutuhkan peelitian lebih lanjut mengenai hal ini, penelitian ini juga merekomendasikan adanya kolaborasi ahli hadits dan ahli tafsir serta juga ahli tasawwuf psikoterapi guna mendalami kajian mengenai tafakkur dengan membaca Alqur'an sebagai upaya untuk menenangkan jiwa.

Kata kunci: Alqur'an; Covid-19; Hadits; Ketenangan jiwa; Tafakkur.

\section{Pendahuluan}

Pada era kontemporer seperti sekarang ini, dibutuhkan literatur yang relevan dengan segala permasalahan yang ada. Dan itu berbeda dengan permasalahan pada era sebelumnya. Lahirnya perkembangan serta perubahan situasi sosial, budaya, ilmu pengetahuan dan lain sebagainya mengharuskan adanya epistemologi baru yang relevan. Perubahan situasi pada aspek-aspek tersebut tentunya memberi dampak dan pengaruh terhadap usaha untuk memaknai kembali teks-teks keagamaan (Nasrulloh, 2014). Seperti pada kasus pandemi Covid 19 ini, yang telah berlangsung sejak akhir desember 2020 dan masih berlangsung hingga saat ini. Hal ini tentunya menimbulkan efek psikologis bagi manusia, misalnya karena kesedihan ditinggal mati oleh keluarga, kesedihan karena terdapat keluarga yang terpapar Covid 19, kecemasan tersendiri, juga kejenuhan sebab harus berdiam diri di rumah, selain itu kesulitan ekonomi karena dampak dari social distancing juga ikut andil 
Jurnal Riset Agama, Volume 1, Nomor 2 (Agustus 2021): 412-427

Danendra Ahmad Rafdi/Membaca Alqur'an sebagai Model Tafakkur dalam

Upaya Menenangkan Jiwa Di Masa Pandemi Covid 19: Studi Takhrij dan Syarah Hadis

dalam mempengaruhi kondisi psikologis seseorang (Ahmad Fajar et al., 2020).

Dalam hal ini, tiap orang tentunya membutuhkan solusi tersendiri bagi jiwanya untuk memperoleh ketenangan dan ketentraman demi upaya untuk mengatasi tekanan yang berdampak panjang sebab pandemi ini. Dalam Islam sendiri ada suatu bentuk terapi sebagai upaya untuk menenangkan fikiran dan manjaga kestabilan emosi melalui amalanamalan syariatnya. Ketentraman dan ketenangan jiwa tersebut dapat diperoleh melalui konsistensi dan penghayatan terhadap amalan-amalan ubudiyyah yang dilakukan (Musa \& Saari, 2019). Faktor ketenangan jiwa ini tentunya turut berperan penting bagi kesehatan tubuh manusia, orang yang selalu ceria serta lapang dada dalam menghadapi hidup akan lebih sehat ketimbang orang yang pesimis serta gampang putus asa. Selain terdapat dalam Alquran, berbagai amalan yang disyaria'atkan tersebut juga terdapat dalam hadits. Amalan-amalan ubudiyah tersebut bisa dilakukan dengan membaca Alqur'an, bertasbih, tahmid, tahlil dan istighfar. Upaya tersebut tentunya digunakan untuk mengisi waktu dalam sepanjang hari sebagai dzikir dan tafakkur kepada Allah Swt. Semua ibadah dzikir dan tafakkur tersebut tentunya harus dilakukan dengan iman yang ikhlas, untuk kemudian akan lahir sifat ihsan dalam diri kita yang akan menghantarkan pada ketentraman dan ketenangan jiwa (Haidaroh, 2020).

Dengan demikian, maka segala persoalan akan disandarkan pada keyakinan bahwa Allah Swt. selalu bersama dengan hamba-Nya dan Allah pasti akan mencurahkan pertolongan dan rahmat-Nya, sehingga hilanglah kegelisahan karena setiap persoalan hidup dan lahirlah ketentraman dan ketenangan jiwa. Hal ini tentunya akan langsung berdampak positif terhadap perubahan jasmani atau fisik. Dan secara tidak langsung, ketentraman jiwa tersebut bisa memperkuat sistem imun tubuh yang dalam fenomena ini adalah sebagai bentuk upaya sederhana untuk mencegah penularan Covid-19 serta dampak negatif lain yang timbul darinya (Firdaus et al., 2021).

Sebelumnya telah dilakukan penelitian oleh sejumlah ahli terkait tafakkur dengan membaca Alqur'an sebagai penenang jiwa seperti yang tertera pada tinjauan pustaka ini. Di antaranya ialah Nuronia, Siti (2021), "Hadis tentang Psikosomatis (Studi Ma'ani al-Hadis Riwayat Sunan Ibn Majah Nomor Indeks 3984 Perspektif Psikologi)," Universitas Islam Negeri Sunan Ampel Surabaya. Penelitian ini membahas hadits-hadits tentang psikomatis dengan berfokus pada kajian sanad dan matannya, serta juga membahasnya dalam sudut pandang psikologi. Penelitian ini menggunakan metode kualitatif dengan pendekatan takhrij hadits serta kritik sanad dan matan hadits. Kesimpulan yang didapat dari penelitian ini ialah bahwa hadits-hadits tentang psikomatis yang menjadi objek 
Jurnal Riset Agama, Volume 1, Nomor 2 (Agustus 2021): 412-427

Danendra Ahmad Rafdi/Membaca Alqur'an sebagai Model Tafakkur dalam Upaya Menenangkan Jiwa Di Masa Pandemi Covid 19: Studi Takhrij dan Syarah Hadis

penelitian ini menegaskan agar selalu memelihara kondisi hati untuk senantiasa dalam keadaan yang baik dan positif. Dan hadits-hadits yang dibahas dalam penelitian ini merupakan hadits yang shahih (Nuronia, 2021). Hasanah, Uswatun (2008), "Studi terhadap Tujuan Membaca AlQur'an Masyarakat Dusun Sukorejo Desa Kenteng Kecamatan Susukan Kabupaten Semarang Jawa Tengah," Universitas Islam Negeri Sunan Kalijaga Yogyakarta. Penelitian ini tergolong kepada penelitian lapangan atau field research. Hasil dari penelitian ini ialah bahwa tujuan membaca Alqur'an pada masyarakat di dusun Sukorejo desa Kenteng kecamatan Susukan kabupaten Semarang ini antara lain ingin memperoleh pahala serta meraih ketenangan hati, sebagai psikoterapi penyakit jasmani, ingin memperoleh keselamatan, serta untuk mengusir setan (Hasanah, 2008). Rahim, Kamarul, Zaman, et. al. (2019), “Konsep al-Tafakkur Menurut alSunnah: Kajian Perbandingan Antara Tradisi Meditasi Hindu Di dalam Proses Psikoterapi," Hadith and Aqidah Research Institute, Selangor International Islamic University College Malaysia. Penelitian ini membahas perbandingan antara teori psikoterapi dengan tafakkur menurut hadits dan tradisi meditasi Hindu yang semakin laris digunakan dalam proses psikoterapi. Penelitian ini menggunakan metode kualitatif dengan menggunakan pendekatan deskriptif. Kesimpulan dari penelitian ini ialah bahwa konsep tafakkur menurut hadits mempunyai ciri-ciri yang holistik serta mencakup seluruh aspek psikospiritual seperti tasfiyah alQalbi, al-murāqabah, al-muhāsabah dan dzikir. Tafakkur juga diyakini jauh lebih bermanfaat untuk diterapkan sebagai model psikoterapi alternatif (Rahim et al., 2019).

Penelitian sebelumnya tersebut tentunya turut andil dalam berkontribusi dalam penyusunan kerangka berfikir ini. Pada awal tahun 2020, dunia dihebohkan dengan meluasnya virus varian baru, yang oleh Organisasi Kesehatan Dunia atau World Health Organization diberi nama Severe acute respiratory syndrome coronavirus-2 (SARS-CoV-2) dan nama penyakitnya sebagai Coronavirus Disease 2019 atau COVID-19. Virus ini berawal mula dari Wuhan, Ibukota Provinsi Hubei China, yang ditemukan di akhir Desember tahun 2019 (Yuliana, 2020). Lalu virus ini pun menjadi suatu hal yang mengejutkan serta menakuti seluruh masyarakat dunia, apalagi virus ini telah merenggut ribuan nyawa manusia dalam waktu yang singkat dan cepat. Kurang lebih 200 negara di dunia ini terpapar virus corona, termasuk juga Indonesia. Segala upaya dilakukan dalam rangka mencegah dan mengobati penyebaran virus corona ini, mulai dari lockdown hingga social distancing di kota-kota besar telah diterapkan untuk memutus rantai penyebaran virus Corona ini (Supriatna, 2020).

Secara umum, hadits bemakna segala sesuatu yang disandarkan kepada Nabi Muhammad, baik berupa perkataan, perbuatan, ketetapan 
Jurnal Riset Agama, Volume 1, Nomor 2 (Agustus 2021): 412-427

Danendra Ahmad Rafdi/Membaca Alqur'an sebagai Model Tafakkur dalam Upaya Menenangkan Jiwa Di Masa Pandemi Covid 19: Studi Takhrij dan Syarah Hadis

serta sifat-sifat fisik dan suri tauladannya, dan dalam pengertian sederhana ini, hadits sering juga dipadankan dengan istilah sunnah (Nasrulloh, 2014). Sedangkan takhrij ialah berusaha menemukan sumber hadis dari rujukan aslinya (Iman, 1995). Adapun syarah hadits secara mutlak bermakna menjelaskan serta menjabarkan tentang ucapan, tindakan, dan ketetapan Rasulullah Saw, yang disertai sanadnya (Sanusi, 2019).

Sementara tafakkur adalah aktifitas mengheningkan diri, merenung, memikirkan serta menimbang dengan sungguh-sungguh mengenai alam semesta beserta isinya, dengan tujuan untuk mengasah dan mempertajam perasaan yang ada pada manusia guna memahami seluruh ciptaan dan keagungan Allah SWT. Tafakkur sendiri melingkupi tiga aspek sekaligus dalam diri manusia, yaitu aspek kognisi, afeksi dan spiritual. Secara hakikatnya, tafakur merupakan perwujudan kesadaran untuk memperingati bukti dan kebenaran adanya Allah serta kekuasaan-Nya yang nantinya akan bermuara kepada suatu keyakinan (Zuhby, 2021).

Perintah membaca Alqur'an tidak hanya merupakan sekedar kewajiban. Di balik itu, Alqur'an ternyata juga bertujuan memberi petunjuk serta faedah kepada siapa yang membacanya, dan salah satunya adalah untuk menenangkan jiwa (Affan, 2021). Syeikh Sa'id Hawa pernah menuturkan bahwa Imam al-Ghazali memiliki tiga belas media untuk menyucikan jiwa, dan salah satunya adalah dengan membaca Alqur'an. Membaca Alqur'an mempunyai berbagi manfaat terhadap jiwa, serta itu juga bisa sebagai penyempurna ibadah lain seperti shalat, zakat, puasa dan haji. Manfaat tersebut akan lebih terasa bila dalam pembacaannya disertai dengan adab-adab batin, perenungan, khusyu', serta tadabbur (H $\square$ awwá \& Al-Ghazali., 1999).

Berdasarkan penelusuran terhadap kajian literatur hadits terdahulu, ramai juga yang mengkaji mengenai tafakkur ini dengan menjadikannya sebagai alternatif psikoterapi. Namun, tafakkur dengan cara membaca Alqur'an menurut hadits sebagai upaya untuk menenangkan jiwa ini masih kurang didapati dan dibahas oleh berbagai pihak. Maka dalam penelitian ini, penulis mendapati model al-Tafakkur dengan membaca Alqur'an menurut hadits dengan mencoba memberikan sedikit perspektif baru menganai panduan psikoterapi untuk menenangkan jiwa. Namun dalam penlitian ini, hanya dibahas satu hadits mengenai permasalahan ini, yakni hadis riwayat imam al-Bukhari No. 4203 Kitab Tafsir Alqur'an Bab Surat Ali Imran Ayat 190 dan pada versi Fathul Bari No. 4569 (Al Asqalani, 2003).

Model tafakkur dalam kacamata Islam ternyata memiliki arti yang lebih holistik serta luas dibanding dengan meditasi lainnya. Ternyata dalam hadits Rasulullah nampak bahwa Islam sendiri terbukti telah merintis konsep al-Tafakkur ini sebagai sarana menajamkan taqwa, 
Jurnal Riset Agama, Volume 1, Nomor 2 (Agustus 2021): 412-427

Danendra Ahmad Rafdi/Membaca Alqur'an sebagai Model Tafakkur dalam Upaya Menenangkan Jiwa Di Masa Pandemi Covid 19: Studi Takhrij dan Syarah Hadis

keimanan, motivasi hidup, penyucian diri, serta sebagai psikoterapi dan psikospiritual (Rahim et al., 2019). Bertafakur dalam menghadapi wabah virus Covid-19 ini ternyata bisa dengan cara membaca Alqur'an seraya meminta perlindungan kepada Allah SWT, berikhtiar, bertawakal, dan yakin akan pertolongan yang Allah SWT berikan.

Dan berdasarkan paparan di atas, penulis berupaya membangun formula penelitian ini. Rumusan masalah penelitian ini adalah terdapat syarah hadits tentang membaca Alqur'an sebagai model tafakkur dalam upaya menenangkan jiwa di masa pandemi Covid 19. Pertanyaan penelitian ini adalah bagaimana syarah hadits tentang membaca Alqur'an sebagai model tafakkur dalam upaya menenangkan jiwa di masa pandemi Covid 19. Adapun pertanyaan terperinci adalah sebagai berikut; 1) Bagaimana teks hadits tentang membaca Alqur'an; 2) Bagaimana kualitas hadits tentang membaca Alqur'an; dan 3) Bagaimana syarah hadits tentang membaca Alqur'an sebagai model tafakkur dalam upaya menenangkan jiwa di masa pandemi Covid 19. Tujuan penelitian ini yaitu membahas syarah hadits tentang membaca Alqur'an sebagai model tafakkur dalam upaya menenangkan jiwa di masa pandemi Covid 19. Penulis juga berharap bahwa dengan adanya penelitian ini bisa menambah serta mendalami wawasan terhadap khalayak umum khususnya pada masyarakat Islam mengenai tafakkur dengan membaca Alqur'an sebagai upaya menenangkan jiwa pada masa pandemi Covid 19.

\section{Metode Penelitian}

Penelitian ini merupakan jenis penelitian kualitatif yang dilakukan melalui studi pustaka atau literature review (Darmalaksana, 2020a). Kemudian pada penelitan ini metode yang dipakai ialah dengan mengaplikasikan metode takhrij dan syarah hadits (Darmalaksana, 2020b), kemudian isu yang diangkat ini akan dianalisis dengan pandangan kontemporer (Darmalaksana, 2020c).

\section{Hasil dan Pembahasan}

Hasil dari penelitian serta pembahasan tersaji dalam beberapa hal berikut ini.

\section{Teks Hadits tentang Membaca Alqur'an sebagai Model Tafakkur}

Setelah dilakukan penelusuran pada aplikasi Ensikolpedi Hadits Kitab 9 Imam (Saltanera, 2015), ditemukanlah beberapa hadits yang berkaitan, namun yang akan menjadi pembahasan pada penelitian ini ialah hadits riwayat Imam al-Bukhari No. 4203 Kitab Tafsir Alqur'an Bab Surat Ali Imran Ayat 190 dan pada versi Fathul Bari No. 4569, berikut ini: 
Jurnal Riset Agama, Volume 1, Nomor 2 (Agustus 2021): 412-427

Danendra Ahmad Rafdi/Membaca Alqur'an sebagai Model Tafakkur dalam Upaya Menenangkan Jiwa Di Masa Pandemi Covid 19: Studi Takhrij dan Syarah Hadis

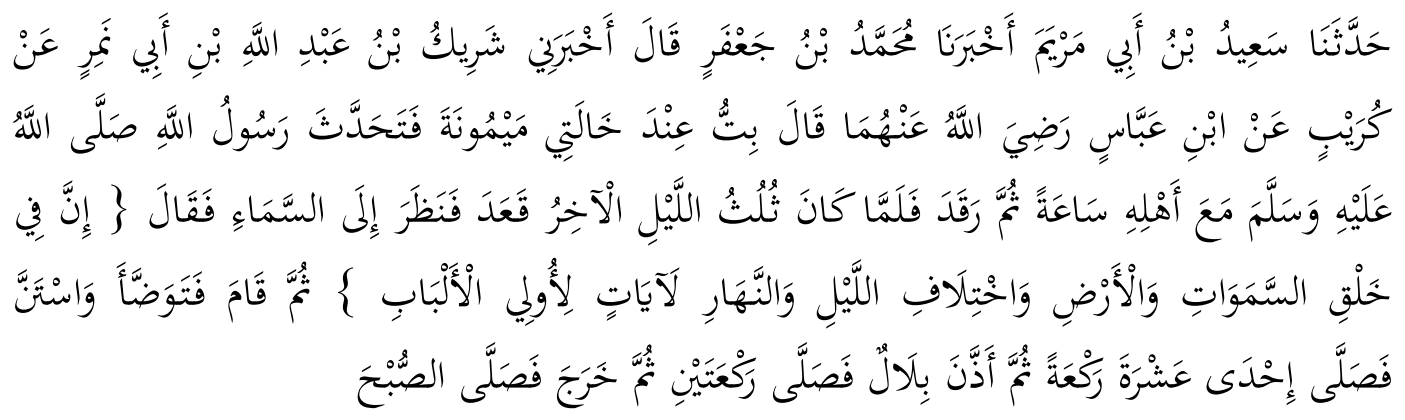

Artinya: Telah menceritakan kepada kami Sa'id bin Abu Maryam; Telah mengabarkan kepada kami Muhammad bin Ja'far berkata; Telah mengabarkan kepadaku Syarik bin 'Abdullah bin Abu Namir dari Kuraib dari Ibnu 'Abbas radliallahu 'anhuma dia berkata; suatu ketika aku bermalam di rumah bibiku Maimunah, aku mendengar Rasulullah shallallahu 'alaihi wasallam berbincangbincang bersama istrinya sesaat. Kemudian beliau tidur. Tatkala tiba waktu sepertiga malam terakhir, beliau duduk dan melihat ke langit lalu beliau membaca; "Sesungguhnya dalam penciptaan langit dan bumi, dan silih bergantinya malam dan siang terdapat tandatanda bagi orang-orang yang berakal" (Ali Imran; 190). Lalu beliau berwudlu dan bersiwak, kemudian shalat sebelas raka'at. Setelah mendengar Bilal adzan, beliau shalat dua raka'at kemudian beliau keluar untuk shalat subuh.

\section{Daftar Rawi dan Sanad hadits}

Takhrij hadits di atas ditampilkan dalam bentuk tabel berikut ini :

Tabel 1. Daftar Rawi Sanad

\begin{tabular}{|c|c|c|c|c|c|c|c|c|}
\hline \multirow{2}{*}{ No } & \multirow{2}{*}{ Rawi Sanad } & \multicolumn{2}{|c|}{$\begin{array}{c}\text { Lahir / } \\
\text { wafat }\end{array}$} & \multirow{2}{*}{ Negeri } & \multirow{2}{*}{ Kuniyah } & \multicolumn{2}{|c|}{ Komentar Ulama' } & \multirow{2}{*}{ Thobaqat } \\
\hline & & $\mathbf{L}$ & $\mathbf{W}$ & & & + & - & \\
\hline 1 & $\begin{array}{l}\text { Abdullah } \\
\text { bin 'Abbas } \\
\text { bin Abdul } \\
\text { Muthalib } \\
\text { bin Hasyim }\end{array}$ & & $\begin{array}{l}58 \\
\mathrm{H}\end{array}$ & $\begin{array}{l}\text { Marur } \\
\text { Rawdz }\end{array}$ & $\begin{array}{l}\text { Abu al- } \\
\text { 'Abbas }\end{array}$ & & & Shahabat \\
\hline 2 & $\begin{array}{l}\text { Kuraib bin } \\
\text { Abi Muslim, } \\
\text { maula Ibnu } \\
\text { 'Abbas }\end{array}$ & & $\begin{array}{l}98 \\
\mathrm{H}\end{array}$ & Madinah & $\begin{array}{l}\text { Abu } \\
\text { Rusydain }\end{array}$ & $\begin{array}{l}\text { Yahya bin } \\
\text { Ma'in: } \\
\text { Tsiqah; } \\
\text { Muhammad } \\
\text { bin Sa'ad: } \\
\text { Tsiqah; } \\
\text { Ibnu } \\
\text { Hibban: }\end{array}$ & & $\begin{array}{l}\text { Tabi'in } \\
\text { Kalangan } \\
\text { Pertengahan }\end{array}$ \\
\hline
\end{tabular}


Jurnal Riset Agama, Volume 1, Nomor 2 (Agustus 2021): 412-427

Danendra Ahmad Rafdi/Membaca Alqur'an sebagai Model Tafakkur dalam

Upaya Menenangkan Jiwa Di Masa Pandemi Covid 19: Studi Takhrij dan Syarah Hadis

\begin{tabular}{|c|c|c|c|c|c|c|c|}
\hline & & & & & $\begin{array}{l}\text { Tsiqah; } \\
\text { Ibnu Hajar } \\
\text { al-Atsqalani: } \\
\text { Tsiqah; } \\
\text { Adz- } \\
\text { Dzahabi: } \\
\text { Tsiqah. }\end{array}$ & & \\
\hline 3 & $\begin{array}{l}\text { Syarik bin } \\
\text { Abdullah } \\
\text { bin Abi } \\
\text { Namir }\end{array}$ & $\begin{array}{c}144 \\
\mathrm{H}\end{array}$ & Madinah & 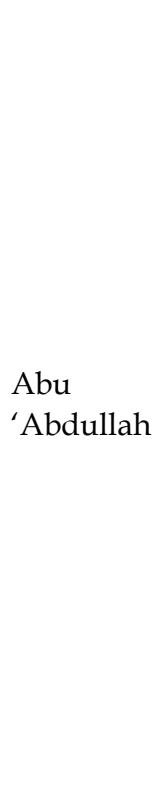 & $\begin{array}{l}\text { An-Nasa'i: } \\
\text { Laisa bihi } \\
\text { Ba'ts; } \\
\text { Yahya bin } \\
\text { Ma'in: Laisa } \\
\text { bihi Ba'ts; } \\
\text { Ibnu Sa'ad: } \\
\text { Tsiqah; } \\
\text { Abu Daud: } \\
\text { Tsiqah; } \\
\text { Ibnu } \\
\text { Hibban: } \\
\text { Tsiqah; } \\
\text { Ibnul Jarud: } \\
\text { Laisa bihi } \\
\text { ba'ts. }\end{array}$ & $\begin{array}{l}\text { Ibnu } \\
\text { Hajar al- } \\
\text { Atsqalani: } \\
\text { Shaduq, } \\
\text { Terdapat } \\
\text { kesalahan }\end{array}$ & $\begin{array}{l}\text { Tabi'in } \\
\text { kalangan } \\
\text { biasa }\end{array}$ \\
\hline 4 & $\begin{array}{l}\text { Muhammad } \\
\text { bin Ja'far bin } \\
\text { Abi Katsir }\end{array}$ & & Madinah & & $\begin{array}{l}\text { Yahya Bin } \\
\text { Ma'in: } \\
\text { Tsiqah; } \\
\text { Ibnu } \\
\text { Madini: } \\
\text { Ma'ruf; } \\
\text { An-Nasa'i: } \\
\text { Shalih; } \\
\text { Ibnu } \\
\text { Hibban: } \\
\text { Tsiqah; } \\
\text { Al-Ajli: } \\
\text { Madani } \\
\text { Tsiqah; } \\
\text { Ibnu Hajar } \\
\text { al-Atsqalani: } \\
\text { Tsiqah; } \\
\text { Adz- } \\
\text { Dzahabi: }\end{array}$ & & $\begin{array}{l}\text { Tabi'ut } \\
\text { Tabi'in } \\
\text { kalangan tua }\end{array}$ \\
\hline
\end{tabular}


Jurnal Riset Agama, Volume 1, Nomor 2 (Agustus 2021): 412-427

Danendra Ahmad Rafdi/Membaca Alqur'an sebagai Model Tafakkur dalam Upaya Menenangkan Jiwa Di Masa Pandemi Covid 19: Studi Takhrij dan Syarah Hadis

\begin{tabular}{|c|c|c|c|c|c|c|c|}
\hline & & & & & & Tsiqah. & \\
\hline 5 & $\begin{array}{l}\text { Sa'id bin } \\
\text { Abi Maryam } \\
\text { al-Hakam } \\
\text { bin } \\
\text { Muhammad } \\
\text { bin Salim }\end{array}$ & & $\begin{array}{c}224 \\
\mathrm{H}\end{array}$ & Maru & $\begin{array}{l}\text { Abu } \\
\text { Muhammad }\end{array}$ & $\begin{array}{l}\text { Al-Ajli: } \\
\text { Tsiqah; } \\
\text { Abu Hatim } \\
\text { Ar-rozy: } \\
\text { Tsiqah; } \\
\text { Yahya bin } \\
\text { Ma'in: } \\
\text { Tsiqah; } \\
\text { Ibnu } \\
\text { Hibban: } \\
\text { Tsiqah. }\end{array}$ & $\begin{array}{l}\text { Tabi'ul } \\
\text { Atba' } \\
\text { kalangan tua }\end{array}$ \\
\hline 6 & $\begin{array}{l}\text { Abu } \\
\text { Muhammad } \\
\text { bin Ismail } \\
\text { bin Ibrahim } \\
\text { bin al- } \\
\text { Mughirah } \\
\text { bin } \\
\text { Bardizbah } \\
\text { al-Ju'fi al- } \\
\text { Bukhari }\end{array}$ & $\begin{array}{c}194 \\
\mathrm{H}\end{array}$ & $\begin{array}{c}256 \\
\mathrm{H}\end{array}$ & Bukhara & $\begin{array}{l}\text { Abu } \\
\text { Abdullah }\end{array}$ & $\begin{array}{l}\text { Imam } \\
\text { Hadits }\end{array}$ & Mudawwin \\
\hline
\end{tabular}

Tabel 1 meruapakan daftar rawi dan sanad hadits riwayat Imam alBukhari No. 4203 Kitab Tafsir Alqur'an Bab Tafsir Surat ali-Imran Ayat 190 dan pada versi Fathul Bari No. 4569. Pada tabel di atas, terdapat sebuah matrik rawi-sanad yang menunjukkan enam orang rawi mulai dari mukharrij sampai mudawwin. Hanya satu orang rawi yang tidak diketahui tahun lahir beserta wafatnya, yakni Muhammad bin Ja'far bin Abi Katsir. Semua ulama memberikan komentar positif terhadap semua rawi, kecuali pada Syarik bin Abdullah bin Abi Namir terdapat penilaian negatif berupa shaduq, terdapat kesalahan dari Ibnu hajar al-Atsqalani. Dalam ilmu hadits, rawi terakhir merupakan sanad pertama, sedangkan rawi pertama merupakan sanad terakhir (Darmalaksana, 2021b).

\section{Kualitas Hadits Membaca Alqur'an sebagai Model Tafakkur}

Hadits bisa dikatakan shahih bila sanadnya bersambung dari awal sampai akhir, disampaikan oleh rawi-rawi yang adil, memiliki kemampuan menghapal yang sempurna (dhabith), serta tidak ada penyelisihan dengan perawi yang lebih terpercaya darinya (syadz) dan tidak ada i'llat yang berat (Al-Qaththan, 2005). Pada tabel 1 nampak bahwa Ibnu Hajar menilai Syarik bin Abdullah bin Abi Namir shaduq dan terdapat kesalahan, akan tetapi ada tiga ulama' yang menilainya tsiqah, ada juga yang menilainya laisa bihi ba'ts. Sedangkan menurut Ibnu Ma'in 
Jurnal Riset Agama, Volume 1, Nomor 2 (Agustus 2021): 412-427

Danendra Ahmad Rafdi/Membaca Alqur'an sebagai Model Tafakkur dalam Upaya Menenangkan Jiwa Di Masa Pandemi Covid 19: Studi Takhrij dan Syarah Hadis

laisa bihi ba'ts itu juga bisa dikatakan tsiqah (Al-Qaththan, 2005). Setealah ditelusuri, ternyata hadits ini juga dikuatkan dengan hadits lain yakni hadits riwayat Imam Muslim No. 376 yang seluruh periwatnya tergolong tsiqah dan tidak ada komentar negatif dari para ulama (Saltanera, 2015), dan tidak ada perselisihan antara kedua riwayat ini. Jadi meskipun ada yang berkomentar negatif terhadap salah satu rawi dalam hadits riwayat Imam al-Bukhari di atas, hal itu masih bisa ditambal dengan cara $i$ 'tibar, yakni peningkatan derajat hadits dengan menggunakan syahid dan muttabi' yaitu hadits lain dan juga periwayat lain (Darmalaksana, 2021b). Jadi hadits ini tetap dinilai shahih.

Dalam hadits ini juga terdapat rawi yang tidak diketahui tahun lahir dan wafatnya, yakni Muhammad bin Ja'far bin Abi Katsir. Dan apabila terjadi hal ini, maka dapat diasumsikan bahwa rata rata usia rawi yakni kurang lebih 90 tahun (Darmalaksana, 2021a). Sementara jumhur ulama juga mengatakan bahwa Kitab Shahih Bukhari ini sangat sempurna dan ketat akan syarat yang mengharuskan seorang perawi untuk bertemu langsung dengan gurunya meskipun hanya sekali dalam seumur hidup (Al-Qaththan, 2005). Jadi bisa disimpulkan bahwa sanad hadits ini bersambung. Sedangkan dari segi matan, tidak ditemukan hadits lain yang menentang hadits riwayat imam al-Bukhari ini. Dalam matan hadits ini juga tidak ditemukan hal hal yang membuatnya menjadi cacat, jadi hadits ini terhindar dari syadz dan illat. Oleh karena itu hadis ini berstatus shahih, baik sanad maupun matan.

\section{Syarah Hadits Membaca Alqur'an sebagai Model Tafakkur}

Berkenaan dengan kajian hadits, kata Syarah didefinisikan sebagai suatu upaya untuk menguraikan serta menjelaskan makna yang terkandung pada teks hadits (Muhtador, 2018). Adapun manfaat Syarah hadits adalah untuk menyampaikan pemahaman kepada seorang pengamal hadits (Darmalaksana, 2018). Dan untuk bisa diamalkan, maka sebuah hadits terlebih dahulu harus ditakhrij agar bisa dinyatakan sebagai hadits yang maqbul atau hadits yang diterima (Darmalaksana, 2021b). Seperti yang telah dituliskan sebelumnya, bahwa hadits riwayat alBukhari No. 4203 ini dinyatakan sebagai hadits yang shahih.

Dijelaskan pada kitab Syarah Shahih Bukhari bahwa pada saat Nabi SAW merasakan kehampaan dalam jiwanya, beliau lebih memilih menyendiri untuk bertafakkur, berhenti sejenak dari menikmati kehidupan dunia serat bertujuan untuk menjadikan diri lebih khusyuk (Al-Utsaimin, 2010). Sementara dalam kitab Syarah Shahih Muslim, dijelaskan bahwa hadits riwayat Ibnu Abbas ini menunjukkan disunnahkan-Nya membaca ayat di atas ketika terjaga dari tidur sekaligus dengan memperhatikan langit untuk melakukan tadabbur dan juga tafakkur (An-Nawawi, 2013). 
Jurnal Riset Agama, Volume 1, Nomor 2 (Agustus 2021): 412-427

Danendra Ahmad Rafdi/Membaca Alqur'an sebagai Model Tafakkur dalam Upaya Menenangkan Jiwa Di Masa Pandemi Covid 19: Studi Takhrij dan Syarah Hadis

Sementara dalam Tafsir Ibnu Katsir, dijelaskan bahwa al-Auza i pernah ditanya tentang tujuan tafakkur berdasarkan hadis ini, maka jawab beliau "Rasulullah membaca dan memahami ayat ini secara mendalam dan memikirkan tentang alam semesta yang berada di bawah kekuasaan Allah SWT" (Abdullah, 2004). Kemudian dalam Tafsir alQurtubhi, juga dipaparkan bahwa pada hadits ini Rasulullah membaca ayat tersebut, kemudaian beliau bersegera melaksanakan shalat, dengan begitu beliau telah memadukan antara bertafakkur dengan sholat dan melakukannya secara bersamaan (Al-Qurthubi, 2008). Imam ar-Razi juga berkata dalam tafsirnya bahwa yang dimaksud pada ayat ini ialah menjemput hati dan ruh setelah menegaskan tentang makhluk yang diciptakan, yang tujuan-Nya ialah untuk tenggelam dengan memperhatikan makrifat terhadap tuhan yang al-Haq (Abdul Karim Amrullah, 2003).

Adapun mengenai maksud dari Ulul Albab ialah karena kita manusia, kita berfikir, mempunyai renungan dan mempunyai fikiran. Sebagaimana yang dikatakan Quraish Shihab bahwa Ulul Albab adalah orang-orang yang memiliki akal yang murni, yang merenungkan tentang fenomena alam raya akan dapat sampai kepada bukti yang sangat nyata tentang keesaan dan kekuasaan Allah SWT (Shihab, 2002).

Bisa dipahami bahwa hadits ini memuat intruksi untuk merenungkan alam, langit dan bumi. Langit yang melindungi kita dan bumi yang terhampar tempat kita hidup, semuanya itu penuh dengan ayat-ayat dan juga tanda-tanda akan kebesaran Allah SWT. Tafakkur memang kental dan penuh akan kebermaknaan hidup, dan lewat pemaknaan terhadap keagungan dan kemuliaan serta kekuasaan Allah tersebut, manusia akan diliputi dengan kondis hati yang tenang dan damai. Dengan demikian, maka semua bentuk praktek ubudiyah akan dilakukan dengan setulus hati agar mendapatkan makna yang sesungguhnya, seperti yang dilakukan oleh Rasulullah yang melakukan shalat sehabis melakukan tafakkur tersebut.

Berkaitan dengan tafakkur, maka tidak bisa lepas juga dari dzikir, karena Dzikir dan fikir adalah dua perkara yang membuat terbukanya hati manusia dalam menerima ayat-ayat Allah (Badri \& Husnan, 1996). Sebagaimana dijelaskan oleh Ibnu Hajar al-Atsqalani yang mengamini pernyataan al-Qadhi Iyadh Rahimahullah bahwa dzikir kepada Allah Ta'ala itu ada dua macam; yaitu dzikir dengan hati, dan dzikir dengan lisan. Adapun dzikir dengan hati juga ada dua macam; Yang pertama adalah memikirkan serta merenungi keagungan Allah Ta'ala, kemuliaanNya, kekuasaan-Nya dan tanda-tanda kebesaran-Nya, baik yang berada di langit maupun di bumi. Kemudian yang kedua adalah dzikir dengan hati ketika ada perintah agama yang harus dijalankan dan larangan agama yang harus dijauhi (Al Asqalani, 2003). 
Jurnal Riset Agama, Volume 1, Nomor 2 (Agustus 2021): 412-427

Danendra Ahmad Rafdi/Membaca Alqur'an sebagai Model Tafakkur dalam Upaya Menenangkan Jiwa Di Masa Pandemi Covid 19: Studi Takhrij dan Syarah Hadis

Ar-Razi juga menambahkan bahwa ada jenis zikir ketiga yakni zikir anggota badan sebagai pelengkap bagi dzikir hati tersebut. Dzikir juga bisa dilakukan dengan melaksanakan perintah sholat wajib atau menjalankan syari'at dalam Islam seperti membaca al-Quran, menuntut ilmu dan lain-lain. Hal itu tentunya bertujuan tidak lain sebagai sarana mengabdikan diri dan taat kepada Allah SWT (Al Asqalani, 2003). Imam Nawawi juga menerangkan bahwa makna dzikir sebenarnya itu tidak hanya terbatas dengan melafazkan lafaz dzikir seperti tasbih, tahlil, takbir dan tahmid ataupun yang lain, akan tetapi segala jenis amal yang dilakukan kerana Allah SWT juga termasuk sebagai dzikir (An-Nawawi, 2013).

Sementara Imam al-Ghazali dalam hal ini menekankan betapa vitalnya peran al-Qur'an. Imam al-Ghazali ternyata memadukan muhasabah dan tafakkur mengenai Kalam Allah tersebut dengan perbuatan yang bersandar pada pemeliharaan ibadah. Pemeliharaan ibadah ini menurut beliau dimulai dengan pelaksanaan dan konsistensi terhadap shalat-shalat fardhu yang serta shalat-shalat sunnah (H $\square$ awwá \& Al-Ghazali., 1999). Ini menunujukkan bahwa tafakkur menjadi media antara hamba dengan Tuhannya. Melalui tafakkur, seorang manusia akan menyadari tujuan sebenarnya dalam yakni untuk beribadah kepada-Nya. Berpadunya dzikir dan fikir dalam diri manusia akan mengantarkannya kepada proses penyucian diri atau tazkiyatun-nafs.

Bertafakkur tentang alam semesta yang hakekatnya merupakan kekuasaan Allah SWT rupanya akan menambah rasa mahabbah kepadaNya. Rasa cinta kepada Allah SWT tersebut juga akan dapat dikembangkan lagi dengan bertafakkur tentang sifat-sifat dan nama-nama Allah SWT. Hal inilah yang kemudian akan meningkatkan keimanan seorang manusia sehingga akan melahirkan ketenangan dalam jiwa.

\section{Kesimpulan}

Kemunculan virus Covid-19 pada akhir tahun 2019 serta pemberlakuan aturan oleh pemerintah sudah mengakibatkan efek psikologis bagi masyarakat di Indonesia. Imbas tersebut berupa kekhawatiran, kepanikan, kecemasan, ketakutan dan juga kejenuhan. Dan di sisi lain pikiran-pikiran itu semakin meningkatkan kadar kekacauan jiwa seseorang karena kondisi pikiran yang selalu negatif. Dan dari segi Ilmu Hadits, berdasarkan data-data yang telah dijelaskan sebelumnya, dapat diketahui kualitas hadis riwayat al-Bukhari No. 4203 berstatus shahih baik dari segi sanad maupun matan hadits, meskipun dengan catatan ada satu orang rawi yang dinilai terdapat kesalahan oleh Ibnu Hajar al-Atsqalani yakni Syarik bin Abdullah bin Abi Namir, namun riwayatnya tetap diterima karena tidak mengindikasikan adanya tadlis, tahun wafat dan lahir antara periwayat tersebut juga mengindikasikan 
Jurnal Riset Agama, Volume 1, Nomor 2 (Agustus 2021): 412-427

Danendra Ahmad Rafdi/Membaca Alqur'an sebagai Model Tafakkur dalam

Upaya Menenangkan Jiwa Di Masa Pandemi Covid 19: Studi Takhrij dan Syarah Hadis

adanya pertemuan atau sezaman, serta dia pun dinilai tsiqah oleh ulama' hadis lain. Berkaitan dengan kehujjahan hadits tentang tafakkur dengan membaca alqur'an ini, diketahui bahwa hadits ini maqbul atau dapat diamalkan, karena tidak bertentangan dengan hadits lain, serta tidak bertentangan dengan akal sehat.

Berkenaan dengan upaya untuk menenangkan jiwa ini, hadits Rasulullah SAW terbukti memiliki sebuah alternatif psikoterapi yang komprehensif. Untuk itu, ketenangan jiwa merupakan kondisi yang harus terus diraih oleh setiap orang supaya ia terus berada dalam kebaikan. Karena dengan adanya musibah ini, hendaknya menyadarkan manusia tentang makna ujian hidup, peringatan atas sikap teledor kita dalam kehidupan serta mengarahkan kita kepada jiwa yang sabar dan ikhlas. Dengan adanya musibah virus Covid-19 tersebut keyakinan hendaknya semakin menebal, dan perasaan kedekatan dengan Allah menjadi semakin mendalam. Ini dapat diupayakan salah satunya dengan membaca Alqur'an sebagai niat untuk bertafakkur serta mendekatkan diri kepada allah swt. Tafakkur sendiri juga dapat diartikan sebagai kegiatan merenung seorang manusia untuk menemukan hikmah dibalik musibah agar menguatkan iman setiap manusia. Makna tafakkur sebenarnya yaitu selalu meminta perlindungan kepada Allah SWT dengan berdoa dan bertawakkal kepada-Nya, seraya menjalankan amalan amalan ubudiyah guna mendekatakan diri kepada-Nya.

Efek tafakkur dengan membaca Alqur'an tersebut akan melahirkan kondisi jiwa yang tenang, sebuah pencerahan batin serta penghayatan akan peristiwa yang dialami. Tafakkur ini pun dapat menjadi sebuah media terapi spiritual atas problem jiwa yang ditimbulkan karena virus Covid-19 dan menjadikan kondisi jiwa membaik serta lebih sabar, lebih ikhlas, lebih tenang, dan mampu menerima situasi sebagai wujud ridha akan ketentuan Allah SWT. Akhirnya kita bisa menyimpulkan pula bahwa meskipun membaca Alqur'an bukan satu-atunya cara untuk menuju ketenangan jiwa, namun membaca Alqur'an adalah cara termudah lagi dapat dilakukan oleh masyarakat awam sekalipun.

Penelitian ini diharapkan dapat memberikan manfaat dan informasi kepada khalayak umum, terutama yang ingin mengetahui takhrij hadits mengenai tafakkur dengan membaca Alqur'an. Penelitian ini memiliki keterbatasan karena hanya melakukan takhrij dan syarah hadis tanpa melakukan kajian mendalam terkait dengan ilmu psikoterapi dan ilmu tasawuf, sehingga dibutuhkan penelitian lebih lanjut dari bidang ilmu tasawuf psikoterapi. Penelitian ini merekomendasikan diadakannya kolaborasi penelitian lebih lanjut antara ahli ilmu hadis dan ilmu tafsir serta juga ahli tasawwuf psikoterapi untuk mengkaji lebih dalam terkait tafakkur dengan membaca Alquran sebagai upaya untuk menenangkan jiwa. 
Jurnal Riset Agama, Volume 1, Nomor 2 (Agustus 2021): 412-427

Danendra Ahmad Rafdi/Membaca Alqur'an sebagai Model Tafakkur dalam

Upaya Menenangkan Jiwa Di Masa Pandemi Covid 19: Studi Takhrij dan Syarah Hadis

\section{Daftar Pustaka}

Abdul Karim Amrullah, A. M. (2003). Tafsir Al-Azhar Jilid 2. Pustaka Nasional PTE LTD Singapura.

Abdullah. (2004). Tafsir Ibnu Katsir Jilid 2 (A. Ghoffar (ed.); Terjemahan). Pustaka Imam Asy-Syafi'i.

Affan, M. (2021). Membaca Al-Qur'an Sebagai Sarana Memperoleh Ketenangan Jiwa. https:/ / doi.org/10.17605/OSF.IO/867HS

Ahmad Fajar, D., Zaenal Arifin, I., Tajiri, H., \& Marlina, E. (2020). Membentuk ketahanan mental berbasis tasawuf melalui dzikir lathifah sebagai metode terapi terhadap efek pandemi covid 19.

Al-Qaththan, M. (2005). Mabahits fi Ulumil Hadits: Pengantar Studi Ilmu Hadits (M. Abdurrahman \& M. Ihsan (ed.); Edisi Indo). Pustaka AlKautsar.

Al-Qurthubi. (2008). Tafsir Al-Qurthubi Jilid 4 (D. Rosyadi, N. Haq, Fathurrahman, \& A. Zubairi (ed.); Terjemah). Pustaka Azzam.

Al-Utsaimin, M. B. S. (2010). Syarah Shahih Al-Bukhari (A. I. Al-Atsarai (ed.); Edisi Terj). Darus Sunnah.

Al Asqalani, I. H. (2003). Fathul Baari Shahih Al Bukhari. In Amiruddin (Ed.), Riyadh: Maktabah Darussalam (Edisi Indo). Pustaka Azzam.

An-Nawawi, M. A. Z. Y. (2013). Al-Minhaj fi Syarh Shahih Muslim bin AlHajjaj ( Shahih Muslim Bi Sharh An-Nawawi) (A. K. Wawan Djunaedi (ed.); Terjemahan). Darus Sunnah.

Badri, M., \& Husnan, U. S. (1996). Tafakkur Perspektif Psikologi Islam (D. Mulyana (ed.)). Remaja Rosdakarya.

Darmalaksana, W. (2018). Paradigma Pemikiran Hadis - Digital Library UIN Sunan Gunung Djati Bandung. http:/ / digilib.uinsgd.ac.id/8585/

Darmalaksana, W. (2020a). Metode Penelitian Kualitatif Studi Pustaka dan Studi Lapangan. Pre-print Digital Library UIN Sunan Gunung Djati Bandung, 1-6. http://digilib.uinsgd.ac.id/32855/1/Metode Penelitian Kualitatif.pdf

Darmalaksana, W. (2020b). Prosiding Proses Bisnis Validitas Hadis untuk Perancangan Aplikasi Metode Tahrij.

Darmalaksana, W. (2020c). Penelitian Metode Syarah Hadis Pendekatan Kontemporer: Sebuah Panduan Skripsi, Tesis, dan Disertasi. Diroyah: Jurnal Studi Ilmu Hadis, 5(1), 58-68. https://journal.uinsgd.ac.id/index.php/Diroyah/article/view/9468

Darmalaksana, W. (2021a). Herbal Daun Senna dalam Pengobatan Covid-19: Studi Takhrij Hadis.

Darmalaksana, W. (2021b). Kosmetik Halal Sebagai Lifestyle untuk Kesehatan: Studi Takhrij dan Syarah Hadits.

Firdaus, F., Hardiningrum, A., \& Nurjannah, S. (2021). Penurunan Kecemasan pada Anak Sekolah dengan Membaca Alquran Selama Pandemic Covid 19. Jurnal Keperawatan, 13(1), 209-214. 
Jurnal Riset Agama, Volume 1, Nomor 2 (Agustus 2021): 412-427

Danendra Ahmad Rafdi/Membaca Alqur'an sebagai Model Tafakkur dalam Upaya Menenangkan Jiwa Di Masa Pandemi Covid 19: Studi Takhrij dan Syarah Hadis

https:/ / doi.org/10.32583/KEPERAWATAN.V13I1.1140

Haidaroh, R. (2020). Kitab Suci Sebagai Syifa' dan Solusi Menghadapi Wabah Covid-19 [IAIN Kudus]. http:/ / repository.iainkudus.ac.id/4629/

Hasanah, U. (2008). Studi terhadap Membaca Al-Qur'an Masyarakat Dusun Sukorejo Desa Kenteng Kecamatan Sususkan Kabupaten Semarang. https:/ / digilib.uin-suka.ac.id/id/eprint/942/

H $\square$ awwá, S., \& Al-Ghazali. (1999). Mensucikan jiwa : konsep tazkiyatun-nafs terpadu :intisari Ihya' 'Ulumuddin al-Ghazali. 652. https://books.google.com/books/about/Mensucikan_jiwa.html?hl= ms\&id=YAs_OAAACAAJ

Iman, F. (1995). Ilmu Takhrij Al-Hadits: Sejarah dan Urgensi. Alqalam, 10(52), 31.

Muhtador, M. (2016). Sejarah Perkembangan Metode dan Pendekatan Syarah Hadis. Riwayah, 2(2), 259-272.

Musa, N., \& Saâ, C. Z. (2019). Pendekatan psikoterapi Islam dalam menguruskan tekanan pesakit kronik. Jurnal Usuluddin, 47(1), 1-34.

Nasrulloh, N. (2014). Rekonstruksi definisi Sunnah sebagai pijakan kontekstualitas pemahaman Hadits. ULUL ALBAB Jurnal Studi Islam, 15(1), 15-28.

Nuronia, S. (2021). Hadis tentang psikosomatis: studi Ma'ānì al Hadis Riwayat Sunan Ibn Mājah Nomor Indeks 3984 Perspektif Psikologi [Universitas Islam Negeri Sunan Ampel Surabaya]. http:/ / digilib.uinsby.ac.id/id/eprint/ 47249

Rahim, K., Nasir, K., \& Mamat, S. (2019). Konsep Al-Tafakkur Menurut Al-Sunnah: Kajian Perbandingan Antara Tradisi Meditasi Hindu di Dalam Proses Psikoterapi. HADIS, 9(18), 195-212. http://hadis.kuis.edu.my/index.php/inhad/article/view/67

Saltanera. (2015). Ensiklopedi Hadits - Kitab 9 Imam. Lembaga Ilmu dan Dakwah Sarana Komunikasi Keagamaan, Lidwa Pusaka. https:/ / store.lidwa.com/get/

Sanusi, A. (2019). TAKHRIJ HADITS. Madani Publishing, Sawangan Depok. http:// repository.uinbanten.ac.id/3484/

Shihab, M. Q. (2002). Tafsir A1 Mishbah: pesan, kesan dan keserasian Al-Q $u r^{\prime}$ an (Vol. 2). Lentera Hati.

Supriatna, E. (2020). Wabah Corona Virus Disease (Covid 19) Dalam Pandangan Islam. SALAM: Jurnal Sosial dan Budaya Syar-i, 7(6). https:/ / doi.org/10.15408/sjsbs.v7i6.15247

Yuliana, Y. (2020). Corona virus diseases (Covid-19): Sebuah tinjauan literatur. Wellness And Healthy Magazine, 2(1), 187-192. https:/ / doi.org/10.30604/WELL.95212020

Zuhby, N. El. (2021). Tafakur Pandemi Covid-19 Perspektif Pendidikan Islam. Fikroh: Jurnal Pemikiran dan Pendidikan Islam, 14(1), 13-27. https:/ / doi.org/10.37812/FIKROH.V14I1.105 
Jurnal Riset Agama, Volume 1, Nomor 2 (Agustus 2021): 412-427

Danendra Ahmad Rafdi/Membaca Alqur'an sebagai Model Tafakkur dalam

Upaya Menenangkan Jiwa Di Masa Pandemi Covid 19: Studi Takhrij dan Syarah Hadis

(Halaman ini sengaja dikosongkan) 